\title{
Klimari buruzko negoziazioak, Kyotoko Protokoloa ordezkatuko duen akordio baterako: Kopenhageko porrotetik Parisko Akordiora
}

\author{
Asier García Lupiola \\ Ekonomia eta Enpresa Fakultatea - Elkano (UPV-EHU)
}

\begin{abstract}
Kyotoko Protokoloa ordezkatuko duen akordio loteslea lortzeko negoziazioak 2007an hasi ziren. 2009ko Kopenhageko Konferentziaren porrotaren ondoren, negoziazioak bertan behera geratu ziren, eta ez zen ia aurrerapenik eman hurrengo bileretan. EBren lidergoa klima-aldaketaren aurkako borrokan, mundu-aliantza batean ahalik eta herrialde gehien bateratzeko ahaleginetan, ahuldu egin zen, AEBk gero eta protagonismo handiagoa hartu zuelako - jarrera pasiboarekin eta oztopatzailearekin-, bai eta Txinak ere. Nahiz eta EBk berriro sustatu zituen negoziazioak, badirudi Parisko Akordioa posible izan zela AEBren eta Txinaren inplikazio handiagatik; horrek aldi berean dakar askok zalantzan jartzea benetan emaitza arrakastatsua izango dela.
\end{abstract}

GAKO-HITZAK: Klima-aldaketa $\cdot$ Kyotoko Protokoloa $\cdot$ Lidergoa $\cdot$ Mundu-aliantza - Parisko Akordioa.

\section{Climate negotiations for a Kyoto Protocol substitute agreement: from the failure of Copenhagen to the Paris Agreement}

Negotiations for a binding agreement to replace the Kyoto Protocol began in 2007. Following the failure of the 2009 Copenhagen Conference, negotiations stalled and there was little progress at the next meetings. The EU's leadership in the fight against climate change, which sought to join a global alliance to the largest number of countries, was weakened by the US's growing role, with a passive and even obstructionist stance, and China. Although the negotiations were backed up by the EU, it seems that the Paris Agreement was made possible by the greater involvement of the US and China, which makes many doubt that this is a truly successful outcome.

KEY WORDS: Climate change - Kyoto Protocol · Leadership - Global partnership · Paris Agreement. 


\section{Sarrera ${ }^{1}$}

Gaur egun, klima-aldaketa munduko gizartearen ardura nagusietako bat da. Arazo larri horren ondorioek duten garrantzia hain da handia, ezen fenomeno horren aurkako borroka nazioarteko agendako helburu nagusietakoa bilakatu den. Europar Batasuna (EB) buru da, duela denbora asko, gai honen inguruko beharrezko ekintza globalean, nahiz eta emaitzak Ameriketako Estatu Batuek (AEB) eta Txinak (oraintsuagotik) une bakoitzean betetzen duten zereginaren araberakoak izan.

Klima-aldaketaren aurkako borrokan esanguratsuena den tresna Kyotoko Protokoloa izan da, Klima Aldaketari buruzko Nazio Batuen Esparru Konbentzioan hartu zena, Kyoton 1997ko abenduan eginiko Aldeen III. Konferentzian. Horren bidez, herrialde industrializatuek konpromisoa hartu zuten berotegi-efektuko gasak murrizteko neurriak betetzeko, eta konpromiso horien artean nabarmena zen 2008aren eta 2012aren artean emisio kutsagarriak batez beste \% 5 murrizteko erabakia, erreferentzia gisa 1990eko mailak hartuta² .

\section{1. taula. Kyotoko Protokoloa: 2012rako emisioak murrizteko helburuak, 1990eko mailak erreferentziatzat hartuta.}

\begin{tabular}{|l|c|}
\hline Herrialdea & Helburua \\
\hline $\begin{array}{l}\text { EB-15, Bulgaria, Txekiar Errepublika, Eslovakia, Eslovenia, Esto- } \\
\text { nia, Letonia, Liechtenstein, Lituania, Monako, Errumania, Suitza }\end{array}$ & $-\% 8$ \\
\hline AEB & $-\% 7$ \\
\hline Kanada, Hungaria, Japonia, Polonia & $-\% 6$ \\
\hline Kroazia & $-\% 5$ \\
\hline Zeelanda Berria, Errusia, Ukraina & $\% 0$ \\
\hline Norvegia & $+\% 1$ \\
\hline Australia & $+\% 8$ \\
\hline Islandia & $+\% 10$ \\
\hline
\end{tabular}

Iturria: Kyotoko Protokoloaren B Eranskina (Nazioa Batuak, 1998).

2007an, Baliko Konferentziaren ondoren, negoziazioak hasi ziren, Kyotoko Protokoloa ordezkatuko duen akordio loteslea lortzeko. Hala hasi zen 2015aren amaieran Parisen Nazio Batuen Konbentzioaren bilerara arte luzatu den prozesua. Testu honetan 2007tik 2016ra egon diren Nazio Batuen Klima Aldaketari buruzko Konferentzien eztabaidak eta emaitzak aztertuko dira, Balin finkatutako helburua zein mailatan bete den egiaztatzeko. Aldizkari honen 73. zenbakian (García, 2010), prozesu horren hasiera aztertzen zen, eta, zehazki, 2009ko Kopenhageko Konferentzian izan zen porrota. Porrot horrek aurrerantzeko negoziazioen gidalerroa

1. Testu hau UPV-EHUren ikerkuntzarako laguntza jaso duen ekintzaren emaitza da (NUPV16/04: «Políticas y acciones europeas en materia de medio ambiente, cambio climático y energía»).

2. Protokoloa berotegi-efektuko sei gasen emisioei aplikatzen zaie: karbono dioxidoa $\left(\mathrm{CO}_{2}\right)$, metanoa $\left(\mathrm{CH}_{4}\right)$, oxido nitrosoa $\left(\mathrm{N}_{2} \mathrm{O}\right)$, hidrofluorokarbonoak (HFC), perfluorokarbonoak (PFC), sufre hexafluoruroa $\left(\mathrm{SF}_{6}\right)$. Azken hiruretarako, 1995a har daiteke erreferentzia-urtetzat. 
markatu zuen eta mundu mailan klima-aldaketaren aurkako borrokaren lidergoan eragina izan zuen, hain zuzen ordu arte Europaren esku zegoen lidergoan. Hori dela-eta, aldi berean, negoziaketa horietan potentzia ekonomiko handien jarrera nola bilakatu den aztertuko da, baita nola Kopenhageko Konferentziaren ondoren europar lidergoa ahuldu zen gero, Pariserako bidean, berriro ere sendotzeko.

Hasiera batean, EBk proposamen ausartak aurkeztu zituen, klima-aldaketaren aurkako borrokarako; horrela, mundu mailan lidergoa izan zuen, eremu horretan. Hala ere, Kopenhageko Konferentziatik aurrera, eta krisi ekonomiko globalaren testuinguruan, eztabaida-erritmoa moteldu egin zen, eta protagonismoa hartu zuen AEBren jarrerak, askoz ere pasiboagoak eta ausardia gutxiagokoak, eta Txinak ere, aldi berean, gai horren inguruan zeukan protagonismoa aldarrikatu zuen. EBk proposamen aurreratuenak aurkezten jarraitu bazuen ere, egia esan, exijentzia- eta konpromiso-maila baxuagoa antzematen da, garatutako beste herrialde batzuekiko akordioei bide emateko. Izan ere, «Nazioarteko eragile nagusien eskariak, alegia, Txinarenak edo Ameriketako Estatu Batuarenak, nazioarteko negoziazioen garapenak eta EBk berotegi-efektuko gasen igorle nagusietako bat gisa duen gero eta pisu erlatibo txikiagoak oztopatu egin dute Europaren lidergo klimatikoa» (Lázaro, 2011: 129).

Horrek guztiak ekarri du klima-aldaketaren aurkako borrokan lidergo europar teorikoak, Kyotoko Protokoloa ordezkatuko duen akordioa hartzeko prozesuan, hainbat fasetatik igaro izana. Fase horiek zehazten dituzte testu honen zatiak. Horrela, bigarren zatian aztertzen denez, hasieran, EBk mundu mailako lankidetzaestrategia esanguratsua garatu zuen, baina estrategia horrek ez zuen lortu ezarritako helburua, Kopenhageko porrotak erakutsi bezala. Hirugarren zatian bigarren epea aztertzen da, non krisi ekonomiko globalaren efektuak izan ziren nabarmenak, eta EBk profil baxua izan zuen. Laugarren zatian aztertzen denez, negoziazioen sustapenaren bidez —neurri handi batean EBren aldetik-, Pariseko nolabaiteko arrakasta badirudi AEBren eta Txinaren inplikazio handiaren ondoriozkoa izan zela. Egiten den azterketaren oinarria eta funtsa Nazio Batuen Klima Aldaketari buruzko Konferentzietan aurkeztutako proposamenak eta onartutako dokumentuak dira, baita gaiaren inguruan doktrinak eman dituen iritiziak eta egin dituen balorazioak ere.

\section{Kopenhageko Akordioaren porrota}

Kyotoko Protokoloa ordezkatuko duen nazioarteko akordio berria lortzeko negoziazioak 2007ko abenduan Balin egin zen Nazio Batuen Klima Aldaketari buruzko XIII. Konferentzian hasi ziren. Konferentzian egon ziren eztabaida guztietan, EBren eta AEBren arteko aurrez aurreko jarrera nabarmendu zen. Batasunak helburu gisa emisioen muga 2020rako, 1990ean erregistratutako mailen aldean, \% 25 eta $\% 40$ bitarteko marjinan ezartzea iradoki zuen; AEBk, ordea, aurka egiten zion, sendo, edonolako murrizketa-ehuneko sartzeari. Konferentziaren emaitza Baliko Ekintza Plana izan zen (Nazio Batuak, 2008). Horren bidez, lan-plana ezarri zen, 2012. urtetik harako berotegi-efektuaren gasen emisioak murrizteko konpromiso kuantitatiboak definitzeko; horiek negoziatu egin behar ziren 2009an, nahiz eta dokumentuak ez zuen zehaztu egin beharreko emisioen murrizketa. 
Badirudi Baliko Konferentziaren emaitzak onurak ekarri zizkiola AEBri; izan ere, esan den bezala, ez zen zehaztu konpromiso-maila zehatzik, herrialde garatuenek murrizketei beren gaitasunetan oinarrituta heldu beharko lieketelako. Gainera, garatzeko bidean dauden herrialdeak, besteak beste, Txina eta India, Kyotoko Protokoloaren betebeharretan sartu ez baziren ere, Ipar Amerikaren kexaren aurrean, garapen-bidean dauden herrialdeak beren emisioak murriztera bultzatu ziren. Nolanahi ere, akordioa «une historikoa da, aho batez adosten den neurrian: garapen bidean dauden herrialdeek beren gain hartzen dute ahalegina egiteko beharra, baliabide eta gaikuntzen transferentziari lotuta, eta Ameriketako Estatu Batuek beren gain hartzen dute akordioak hartzeko alde ugariko prozesua eta, horrela, beren jarrera malgutzen dute» (Camarero, 2008: 56).

Hurrengo urratsa 2008ko abenduan izan zen, Poznanen (Polonia). Bertan, Klima Aldaketari buruzko Nazio Batuen XIV. Konferentzia egin zen, eta hura 2009. urtearen amaieran Kopenhagen egin zen biltzarra prestatzeko izan zen. Kopenhagekoan, Kyotoko Protokoloa nola gainditu erabaki behar zen. Emaitzen artean nabarmendu behar da Egokitzapen Funtsa jarri zela martxan, bai eta finantzaketa-akordioa ere; akordio horren bitartez, garapen-bidean dauden herrialdeek zuzenean jo dezakete bertara. Hala ere, garapen-bidean dauden herrialdeak agertu ziren frustratuen; izan ere, haien iritziz, deliberamendu eta eztabaidak oinarrizko printzipio batzuetatik urruntzen ari ziren, besteak beste, zuzentasunetik eta baterako erantzukizun bereizien printzipiotik, kontuan hartuta printzipio horrek ezartzen zuela herrialde guztiek jardun behar zutela egoeren eta baliabideen arabera. Hala ere, Txinak, Indiak, Mexikok eta Brasilek klima-aldaketaren aurkako planak aurkeztu zituzten.

Klima Aldaketari buruzko Nazio Batuen XV. Konferentzia Danimarkako hiriburuan izan zen, 2009ko abenduaren 7tik 18ra bitartean. Aipatu dugun bezala, Biltzarraren helburua izan zen mundu mailako akordio bat lortzea, Kyotoko Protokoloa ordezkatzeko, alegia, juridikoki loteslea zen testu bat adostea, 2013ko urtarrilaren 1ean indarrean sartu beharreko berotegi-efektuko gasen emisioak murrizteko. Nazio Batuek Klima Aldaketari buruzko Gobernu-arteko Taldearen gomendioei jarraitzearen aldeko apustua egin zuten eta berotze globalaren igoera 2 oC-tan mugatzeko, emisioak, 1990eko mailei dagokienez, 2020rako \% 25 eta \% 40 bitartean murriztea eta 2050 erako $\% 50$ eta $\% 80$ bitartean proposatu zuten.

Konferentzian parte hartu zuten herrialdeek hainbat proposamen aurkeztu zituzten, 2020rako berotegi-efektuko gasen emisioak murrizteko. Halaber, herrialde industrializatuek eta garatzeko bidean zeuden ekonomia kutsatzaileenek aurkeztutako proposamenak ere kontuan hartu behar ziren. Horiek direla-eta, benetan eraginkorrak izango ote liratekeen aztertzeko, kontuan izan behar da, emisioen murrizketa-ehunekoak barik, murrizketak kontuan hartzeko erreferentzia urtea. Horrela, nahiz eta badirudien ehuneko batzuk proposamen handinahiak direla, benetan europarrekin batera, errusiarrek eta japoniarrek baino ez zituzten aurkezten planetaren tenperaturaren berotzearen gorakada $2{ }^{\circ} \mathrm{C}$-tara mugatu ahal izateko murrizketa globala lortzeko bideak (Lázaro, 2010: 10). 
2. taula. Emisioak murrizteko Kopenhagen aurkeztutako proposamenak.

\begin{tabular}{|c|c|c|}
\hline Herrialdea & Emisioak murrizteko proposamenak & Erreferentzia \\
\hline AEB & $\%$ 17tik \% 20ra & 2005 \\
\hline Japonia & $\% 25$ & 1990 \\
\hline EB-27 & $\begin{array}{l}\text { \% 20; \% } 30 \text { beste herrialde batzuek halako } \\
\text { esfortzua egiten badute }\end{array}$ & 1990 \\
\hline Txina & $\begin{array}{l}\text { BPGaren unitateko emisioen intentsitate- } \\
\text { murrizketa, \% 40tik \% 45era }\end{array}$ & 2005 \\
\hline India & $\begin{array}{l}\text { BPGaren unitateko emisioen intentsitate- } \\
\text { murrizketa, } \% 20 \text { tik \% 25era }\end{array}$ & 2005 \\
\hline Errusia & $\%$ 22tik \% 25era & 1990 \\
\hline Brasil & $\begin{array}{l}\% 38 \text { tik \% 42ra, agertoki posible desberdinetako } \\
\text { joeren arabera }\end{array}$ & - \\
\hline Hegoafrika & $\begin{array}{l}\text { \% } 34 \text { agertoki posible desberdinetako joeren } \\
\text { arabera }\end{array}$ & - \\
\hline
\end{tabular}

Iturria: Lázaro (2010).

Bileran izan ziren eztabaidek agerian utzi zuten, beste behin ere, herrialdeen artean dauden interes eta asmo desberdinak. Zehazki, «bi funtsezko puntuk agerian utzi zuten klimaren gaiaren inguruan nazioarteko arauketaren egungo eredua ez dela nahikoa: batetik, finantzatzeko moduak eta, bestetik, estatu bakoitzaren erantzukizun zehatzen definizioak» (Márcio eta Bodnar, 2011: 230). Hasieran bazirudien emaitza positiboak egon zitezkeela AEBk Barack Obama presidente izendatu zenetik hartu zuen jarrera-aldaketaren aurrean. Hala ere, gaiaren inguruan nazioarteko konpromisoak hartzearen aurka dauden barne-agente eta eragileek egindako presioak erakutsi zuen, «nahiz eta Obama laguntzaile agertzen saiatu zen EBrekin, bi eragileen arteko lidergoa batura zero den joko bilakatu zela» (Bueno, 2016: 86).

Konferentziaren amaieran, minimo batzuen akordioa hartu zen (Nazio Batuak, 2010a); hura AEBk eta orduan BASIC taldea (Brasil, Hegoafrika, India eta Txina) osatzen zuten herrialdeek batera sustatu zuten. Akordioa ez zen loteslea eta ez zuen ofizialki hartu Nazio Batuen Klima Aldaketaren Konferentziak; hura gogoan hartu zuten aldeek Konferentzian, izan ere, ez zen adostasunez hartu, 192 herrialde parte-hartzaileetako bost aurka agertu baitziren ${ }^{3}$. Kopenhageko Akordio izenez ezagutzen denak helburu izan zuen 2050erako $2{ }^{\circ} \mathrm{C}$-tan eteteko berotze globalaren igoera (akordioaren 1. puntua), eta igoera hori 1, $5^{\circ} \mathrm{C}$-ra jaitsi zitekeen, 2015ean egin zitekeen akordioaren berrikuspenean (12. puntua). Hala ere, ez zitzaien herrialdeei emisioen muga zehatzik ezarri; horiek 2010eko urtarrilean 2020rako emisioak murrizteko helburuak zehaztu behar zituzten (4. puntua) ${ }^{4}$. Akordioak aitortu zuen

3. Britainia Handiak akordioa loteslea izateko eginiko eskariaren aurka agertu ziren herrialdeak Venezuela, Nikaragua, Kuba, Bolivia eta Sudan izan ziren.

4. Garatzeko bidean dauden herrialdeentzat eta gutxi garatutako herrialdeentzat, 2020rako emisioen $\% 15$ eta \% 30 bitarteko murrizketa tartea baliatu zen; garatzeko bidean dauden herrialdeek (besteak beste, Txina, India, Brasil edo Hegoafrika) $\mathrm{CO}_{2}$-aren emisioen erritmoa moteldu behar zuten -baina 
garapen-bidean dauden herrialdeek izan behar dutela ekintzen hartzaile, klimaaldaketari aurre egiteko (3. puntua), eta herrialde industrializatuen eskuetatik 2010 eta 2012 artean 30.000 milioi dolarreko finantza-laguntza ezarri zen, baina ez zen zehaztu nola esleituko zen (8. puntua).

Kopenhageko Akordioa porrotzat jo zen; izan ere, funtsezko elementuak falta zitzaizkion klima-aldaketaren aurkako borroka sendotzeko, kontuan hartuta aurreikusi zela elementu horiek Konferentziaren emaitzen artean egongo zirela, besteak beste, berotegi-efektuko emisioak murrizteko helburu kolektiboak zehaztea edo 2010ean tratatu bat egiteko epe bat ezartzea. Bestalde, ez zuen jasotzen juridikoki loteslea zen akordio baten beharrik. Errudun gisa AEB aipatu zen, edozein akordio lotesletarako ezetza ematen zuelako, bai eta Txina eta India ere; herrialde horien asmoa zen emisioen erritmoari eustea eta, horrela, Nazio Batuek horien erregistroen gainean zuten kontrola saihestea. EB ez zen errudun gisa aipatzen; izan ere, herrialde handien interesez gainera, estatu txikienen interesak ere kontuan hartuko zituen klima-aldaketaren aurkako borrokarako nazioarteko sistema bilatzea defendatu zuen.

Hain zuzen, Europako Batzordeak (2010a) publiko egin zuen estrategia zehatz bat nazioarteko akordio sendoa eta juridikoki loteslea zena lortzeko, herrialde guztien parte-hartzea ekarriko zuena, klimaren aldeko benetako ekintza batean. Proposatutako estrategiak kanpoko proiekzio aktiboa eskatzen zuen Batasunaren aldetik, konfiantza eragingo zuena munduko paktu bat lortzeko, herrialde guztiak kontzientziatuz neurriak har ditzaten beren aukeren arabera. Nolabait, EBk klimaaldaketaren gobernamenduan bete zuen egitekoaren garrantziari eustea eta hura indartzea zen helburua, «emandako adibidearen, egindako ahaleginen eta defendatutako balioen bidez markatutako norabide lidergoaren bitartez» (Lázaro, 2011: 144).

Estrategia hori garatzeko, EBk energia-horniduraren segurtasuna azpimarratu zuen munduko erronka gisa. Horrek esan nahi zuen adostasunik lortu ezean klimaaldaketaren aurka borrokatzeko moduan, Batasunak ahalegina egingo zuela bere lidergoa sendotzeko, ikuspuntu berria hartuz: berotze globalaren aurkako borroka segurtasun energetikoarekin lotzea, herrialde gehienek nazio mailan bakarrik kontuan hartzen duten gaia (Isbell eta Steinberg, 2010: 3). Horretarako, EBk energia berriztagarrien sustapena sendotu zuen, eta, harrezkero, horiek «funtsezko pieza dira Europa mailan oraintsu onetsi diren politika energetikoetan, horien ingurumenorientazioari bide emanez, klima-aldaketaren aurkako borrokaren nazioarteko estrategia baten esparrurik zabalenean» (Mora, 2013: 2).

\section{Negoziazioak Kopenhagetik Parisera bitartean}

Herrialdeek 2020rako berotegi-efektuko gasen emisioak murrizteko helburuak zehazteko epea amaituta, Nazio Batuek (2010b) argitara eman zuten 55 herrialdek beren helburuen berri eman zutela. Kontuan hartu gabe 55 herrialdek bakarrik eman zutela beren helburuen berri -EBtik berez 27, erdia-, nabarmendu zen horiek ez zitzaien mugarik ezarri-, eta nazio pobreenek eta garapen-bidean zeuden uharte-nazioek emisioak arintzeko ekintza boluntarioak har zitzaketen beren gain. 
emisioen \% 78ren arduradun direla eta horien artean AEB eta Txina daudela, bi herrialde kutsatzaileenak. Nazio Batuek nabarmendu zuten, halaber, gas kutsagarrien emisio gehienak egiten zituzten herrialdeen erdiek beren eraginkortasuna hobetu zutela ingurumenaren babesean ${ }^{5}$.

EBtik oso datu positiboak aurkeztu ziren (Europako Batzordea, 2010b); Batasunak, oro har, aurreikusten zuen Kyotoko Protokoloak ezarritako helburuak urte amaierarako betetzea. Hala ere, kontuan hartu gabe estatu kide guztiek beren helburu bereziak betetzen ez zituztela, EBk aitortzen zuen oraintsuko epean lortutako emisioen murrizketa zabala, zati handi batean, krisi globalaren ondoriozko jarduera ekonomiko txikiagoaren eta gasaren prezio txikiagoaren ondorio zela, aintzat hartuta horretara jotzen zela, beste erregai kutsagarri eta garestiago batzuetara jo beharrean.

Urrian, Europako Kontseiluak EBk hurrengo Klima Aldaketari buruzko Nazio Batuen Konferentziara eramango zuen proposamena ezarri zuen ${ }^{6}$. Kopenhagen aurkeztutakoaren ildoari jarraitzen zion; horrela, EBk konpromisoa hartzen zuen \% 30 murrizteko 2020rako berotegi-efektuko gasen emisioak, 1990ko mailen aldean, 2012aren ondoko aldirako akordio globalaren zati gisa; akordio horretan, herrialde garatuek murrizketa erkagarriekin lagunduko zuten eta garapen aurreratuenean dauden herrialdeek beren erantzukizun eta gaitasunen arabera lagunduko zuten ${ }^{7}$. Baina, nahiz eta Europak «juridikoki loteslea den eta Kopenhageko Akordioak ematen dituen orientazio politikoak jasotzen dituen mundu mailako esparru orokorra» lortzeko eskakizuna mantentzen zuen, Europako Kontseiluak erakutsi zuen Cancungo Konferentzia helburu hori lortzeko «tarteko urrats esanguratsua» izateko nahia. Azken batean, EBk onartu zuen Cancunen ez zela akordioa adostuko, Kyotoko Protokoloa ordezkatzen duen testu juridiko loteslearen gainean. Are gehiago, Europako Kontseiluak baieztatu zuen «EBk Kyotoko Protokoloaren testuinguruan bigarren konpromiso aldirako aukera aztertzeko duen borondatea». Nolabait, Europak aitortu zuen AEBren eta Txinaren baterako interesek Cancungo negoziazioen norabidea zehaztuko luketela, eta emaitza Kopenhagekoaren antzekoa izango litzatekeela.

Klima Aldaketari buruzko Nazio Batuen XVI. Konferentzia 2010eko azaroaren 28aren eta abenduaren 10aren artean izan zen, Mexikoko Cancun hirian. Bertan, Konbentzioko 194 estatu kideetako ordezkariek parte hartu zuten; horietako 116k Kopenhageko Akordioa sinatu zuten. Bilerako eztabaidek argi utzi zuten bi talde

5. Horrela ondorioztatu da Klima Lehiakortasunaren Indizetik (Nazio Batuak, 2010c); azterlan hori urtero egiten du Ingurumenerako Nazio Batuen Programak, eta munduko ekonomia-jardueraren \% 97ren eta gas kutsagarrien emisioen \% 96ren arduradun diren 95 herrialderi egiten zaie. Nazio Batuen arabera, ingurumenaren babesean efizientzia gehien hobetu zutenak honako hauek izan ziren: Alemania, Txina eta Hego Korea. Bestalde, zenbait herrialderen hobekuntza esanguratsua nabarmendu zuen, besteak beste: Suedia, Danimarka, Frantzia eta Japonia, garatuenen artean; Filipinas, India, Indonesia, Kenia, Malaysia eta Mexiko garatzeko bidean eta gorantz ari diren herrialdeen artean.

6. 2010 eko urriaren 28ko eta 29ko Bruselako Europako Kontseilua - Presidentetzaren Ondorioak, EUCO 25/10.

7. Akordio globalaren proposamenak jarraitzen zuen izaten emisio globalak $\% 50$ murriztea 2050erako; herrialde garatuen kasuan, talde gisa, \% 80 eta \% 95 bitartean izan behar zuen 2050erako, eta, zehazki, 2020rako \% 30ekoa, 1990eko mailen aldean. 
daudela aurrez aurre: alde batetik, Kyotoko Protokoloaren esparruan konpromisoen bigarren aldia ezartzearen alde agertu zirenak, EB buru izanik eta garatzeko bidean zeuden ekonomia eraginkorrak zituena, besteak beste, Brasil eta Txina. Bestetik, Protokoloaren indarraldia zabaltzeari uko egiten diotenak, horien artean nabarmenak ziren Japonia —ordura arte akordio horren defendatzaile argia izan zen-, Kanada eta Australia; horien kasuan, Protokoloaren irismena mugatua zen, are gehiago kontuan izanik herrialde kutsatzaileenek ez zutela berretsi edo ez zeudela haren pean.

Jarrerak hurbiltzen saiatzeko, EBk uharte-estatu txikiekin eginiko proposamena aurkeztu zuen. Horren bidez eskatzen zen hurrengo Konferentzian legez loteslea zen tresna aurkeztea, Klima Aldaketari buruzko Nazio Batuen Esparru Konbentzioaren pean. Horrela, Konbentzioaren herrialde guztiak, nahiz eta Kyotoko Protokoloa berretsi ez edo haren baldintzapean egon ez, konprometituta leudeke.

Amaierako negoziazioaren emaitza izan zen Cancungo Akordioen onespena (Nazio Batuak, 2011). Ikusita akordioaren puntuak, antzematen da paktu bat zela, eta horren helburua zela herrialde taldeen eskariei erantzutea. Alde batetik, garapen-bidean dauden herrialdeak direla-eta, Kopenhagen aurkeztutako finantzakonpromisoak sendotu ziren eta "Klimarako Funts Berdea» izenekoa sortu zen. Bestetik, herrialde industrializatuen eskariei erantzun zitzaien, besteak beste, AEBkoei, garatzeko bidean zeuden potentzien — bereziki Txina- emisioen murrizketan gardentasuna lortzeko, edo Japoniakoei, akordioan, hainbat motibo tarteko, Kyotoko konpromisoetatik kanpo geratzen ziren herrialde kutsatzaile handiak sartzeko, besteak beste, Txina, India eta AEBren kasuak. Azkenik, Cancungo Akordioek Kyotoren luzapena beren gain hartu zuten 2012a baino lehen, betetzeko epea amaitzen zenean, baina ez zen horren inguruko zehaztapenik ezarri.

Kopenhageko porrotaren ondoren, Cancungo emaitza urrats positibo gisa ikusten zen, baina 2011n Durbanen egin behar zen hurrengo bilerarako itxaropenak murrizten joan ziren, hura hurbildu ahala. Aitortu behar da krisi globala ez zela egokia izan klima-aldaketaren aurkako borroka sustatzeko; izan ere, herrialdeek ulertzen zuten bazituztela beste premiazko ardura batzuk erantzuteko, baina, egia esan, datu batzuek ez zuten aukerarik ematen optimistak izateko. Horrela, batetik, Energiaren Nazioarteko Agentziak esan bezala, 2010ean berotegi-efektuko gasen emisioak sekula baino altuagoak izan ziren; bestetik, Kyotoko Protokoloaren herrialde sinatzaile garrantzitsuek, besteak beste, Kanadak, Japoniak eta Errusiak, ohartarazi zuten ez zutela Protokoloaren bigarren aldia sinatuko, baldin eta herrialde garatuentzako eskakizunak bakarrik ezartzen bazituen, herrialde kutsatzaile guztiak inplikarazi gabe.

EB dela-eta, eurogunearen finantza-krisiaren eta estatu kide batzuentzako egoera larria ekarri zuen nazioarteko krisiaren eraginak eragotzi zuen hain aktibo agertzea Durbango bileraren prestakuntzan, aurreko batzuetan bezala. EBk Hegoafrikara eramandako proposamenean bi ideia nagusi zeuden ${ }^{8}$. Lehenengo eta behin, EB Kyotoko Protokoloa ordezkatuko zuen akordio global eta lotesle berriaren aldekoa

8. 2011ko urriaren 23ko Bruselako Europako Kontseilua - Presidentetzaren Ondorioak, EUCO $52 / 1 / 11$. 
zen, 2015erako adostuta egon beharko lukeena eta, beranduenez, 2020rako indarrean sartu behar zena. Bitartean, Protokoloaren bigarren indarraldiaren aukera onartu zuen, akordio lotesle berri horretara iristeko trantsizioaldi gisa, beraz, 2020a gainditu ezin zuena. Bigarrenik, EBk azpimarratu zuen herrialde garatuek 2020rako emisioan \% 25 eta \% 40 bitartean murrizteko beharra, eta Batasunak bere burua eskaini zuen emisioak \% 30 murrizteko akordio global baten esparruan. Baina, kasu horretan, gainera, garapen-bidean dauden herrialdeek ere beren emisioak 2020rako $\% 15$ eta $\% 30$ bitartean murrizteko beharra azpimarratu zuen.

Klima Aldaketari buruzko Nazio Batuen XVII. Konferentzia 2011ko azaroaren 28aren eta abenduaren 10aren artean izan zen, Hegoafrikako Durban hirian. Kopenhagen gertatutakoaz bestela, eta neurri txikiagoan Cancunen, arreta mediatikoa eskasa izan zen eta axolagabetasun orokorra agerikoa; izan ere, estatuko edo gobernuko buru gutxi bertaratu ziren. Helburua izan zen akordio batera iristea 2020ra arteko Kyotoko Protokoloaren indarraldia luzatzeko, baina, herrialde kutsatzaileenak Protokoloaren zati ez direnez eta, esan bezala, sinatzaile batzuk haren bigarren indarraldiaren aurka agertu zirenez, logikoa zen emaitza positiborik ez izatea.

Bileran, EBrekin batera, Txina izan zen nabarmena, Kyotoko Protokoloaren bigarren indarraldiaren defendatzaile gisa. Arazoa da Txina, oraindik garapenbidean zegoen herrialdetzat hartzen zela kontuan hartuta, planetako herrialderik kutsatzaileena zela, ordurako, eta, garatzeko bidean zeuden ekonomia oso industrializatuekin batera (besteak beste Brasil eta India), emisioak murrizteko Protokoloko betebeharretatik kanpo zeudela. Hala ere, Txinak, klimaren ekintzan gero eta protagonismo gehiago hartzen zihoanez, 2020rako BPGd unitateko $\mathrm{CO}_{2}$-aren emisioak \% 40 eta \% 45 bitartean murrizteko helburua aurkeztu zuen, erreferentzia gisa 2005eko datuak hartuta ${ }^{9}$. Brasilek ere proposamena bultzatzen zuen, eta proposamen horren inguruan G-77 bildu nahi zuen, garapen-bidean zeuden herrialde gehienak proposamenaren alde ager zitezen Durbanen.

Kontrako aldean zegoen, beste behin ere, AEB. Bigarren herrialde kutsatzaileenak (Txinak baino ez zuen gainditzen) jarraitzen zuen esaten ez zuela Kyotoko Protokoloa sinatuko eta, beraz, protokoloaren bigarren indarraldiaren aurka agertu zen. Ipar Amerikako Gobernuak lehentasuna zuen Cancunen adostutako borondatezko konpromisoekin. Hura ordezkatuko zuen akordio globala negoziatzea dela-eta, AEBk ez zion horri aurka egiten, baina baziren 2015a baino lehen negoziazioak hastearen aurkakoak, eta eskatzen zuten garapen-bidean dauden herrialdeentzat ere eta, batik bat, garatzeko bidean zeuden ekonomientzat loteslea zen testua izatea.

9. Horrela egindako proposamenak ez du esan nahi Txinak emisio guztiak murriztuko dituenik epe horretan; izan ere, bere ekonomiaren bilakaerari loturik egonik, eta herrialdearen garapen bizkorra delaeta, gorantz jarraituko lukete, baina erritmo motelagoan. Baina ekarriko luke, ordea, industrien energiaefizientziaren gorakada, eta, egia esan, Txinak murriztu zituen \% 20 BPGd unitateko karbono-emisioak, 2005aren eta 2010aren artean. Gainera, bere proposamenak jasotzen zuen bere energiaren \% 15 iturri berriztagarrietatik etortzea 2020rako, bai eta baso-azaleraren gorakada ere (Lázaro, 2012). 
Bileraren azken egunetan, Nazio Batuek aitortu zuten Durbanen lor zitekeen akordioa bakarrik izango zela 2020rako juridikoki loteslea zen testu globala lortzeko negoziatzen jarraitzeko konpromisoa; AEBko, Txinako eta Indiako ordezkariak horren alde agertu ziren. Bestalde, EBk ahalegina egin zuen jarrera energikoa izateko eta, horretarako, Kyotoko Protokoloa berritzeko bere sinadura honako baldintza honen pean jarri zuen: herrialde kutsatzaileenak jasoko zituen — garatuak izan ala garatzeko bidean dauden herrialdeak izan - akordio global eta lotesle baten negoziazioak hasteko agindua exijituko zuen plana onartzea. Europako proposamenaren alde 120 herrialde baino gehiago agertu ziren, besteak beste, afrikarrak, uharte-estatuak eta ez hain garatuak.

Durbango Konferentziaren amaieran, Ekintza Indarturako Durbango Plataforma izenekoa onetsi zen; bertan, hartutako akordioak jasotzen ziren (Nazio Batuak, 2012). Horrela onetsi zen «protokolo bat, beste tresna juridiko bat edo lege-indarrarekin adostutako ondorio" bat prestatzeko prozesua hastea, tenperaturen batez besteko gorakada 2 ㄷ-ra mugatzeko, zeinak, beranduen, 2015erako amaituta egon behar zuen eta 2020an indarrean sartu. Aldi berean, Kyotoko Protokoloaren bigarren indarraldia onetsi zen (Kyoto II izenez ezagutzen dena), zeinak 2013ko urtarrilean hasi behar zuen. Azkenik, klima-aldaketaren aurrean ahulenak diren eta garapenbidean dauden herrialdeei finantza-laguntza indartu zitzaien, Klimarako Funts Berdea martxan jartzean. Antzeman daitekeenez, EBk lortu zuen eragin nabarmena izatea bileraren azken akordioetan, baina egia da Europako proposamenek gogoan zutela zer zaila zen helburu handinahienak lortzea; baita edukiak beren gain har zitzaketela ere klima-aldaketaren aurkako borroka aktiboagoan sakontzerik nahi ez zuten herrialdeek.

Nolanahi ere, aipatutako edukiak gorabehera, porrota izan zen berriro; izan ere, jarraitzen zen Kyotoko Protokoloa ordezkatuko zuen akordio global loteslea lortu gabe. Hala ere, egia da ere bileraren hasieran zeuden itxaropen baxuen aurrean, hartutako akordioak positiboak izan zirela. Baina, «nahiz eta beharrezkoak izan nazioarteko klima-arkitektura eraikitzen jarraitzeko, ez gaituzte hurbiltzen emisioak mugatzera, ez agudo, ez adostasun zientifikoak eta sozialak gero eta argiago eskatzen duen sendotasunarekin» (Lázaro, 2012: 2). Izan ere, hamarkada bat atzeratu da klima-ekintza globalaren abiaraztea eta, ordura arte, Kyoto II-k bakarrik jartzen zituen baldintzapean emisio globalen $\% 10$ eta $\% 15$ bitartean diren herrialdeak. Hala ere, AEBk eta Txinak, gas kutsagarrien munduko emisioen $\% 40$ baino gehiagoren arduradunak, Durbango Plataforman jasotako akordioak onartu izana aurrerapausotzat har daiteke.

Hurrengo Konferentzia Dohan (Qatar) izan zen, 2012ko azaroaren eta abenduaren artean, eta aurretiko akordioak abiarazten zirela ziurtatzean zentratu zen; izan ere, agerikoa zen orduan foro horrek ez zuela ekarriko bilakaera deigarririk. EB Dohako Konferentziara bertaratu zen Durbanen adostutakoan aurrera egiteko ${ }^{10}$, batez ere Kyotoko Protokoloaren esparruan konpromisorako bigarren aldia hartzeko, bai eta hura ordezkatuko duen eta 2020an indarrean sartuko den tresna juridiko loteslea

10. EBren Kontseilua, Kontseiluaren Ondorioak - Klima Aldaketari buruzko Nazio Batuen Esparru Konbentzioan Aldeen Konferentziak eginiko saioen 18. aldiaren eta Kyotoko Protokoloan Aldeen Bilerak eginiko saioen 8. aldiaren Prestaketa, 15455/12 Dokumentua, 2012ko urriaren 26a. 
hartzeko prozesua hastea adosteari dagokionez ere - Konbentzioaren estatu kide guztiak mende izango dituen akordioa izatea zer garrantzitsua den nabarmenduta-

Hartu zen akordioak, «Dohako Ate Klimatikoa» izenez ezagunak (Nazio Batuak, 2013a), Kyotoko Protokoloari aurkeztutako zuzenketak jaso zituen; horien bidez, formalki ezarri zen konpromisoen bigarren aldiaren hasiera, 2013ko urtarrilaren 1etik aurrera, 2020ko urtarrilaren 31ra arte indarrean egongo dena (Kyoto II). Japoniak, Kanadak eta Zeelanda Berriak Protokoloa baztertu ondoren, luzapenaldian bakarrik geratzen ziren akordioaren mende EB, Australia, Norvegia, Islandia, Kroazia, Kazakshtan, Liechtenstein eta Monako, alegia, munduko emisioen \% 15 baino ez.

\section{3. taula. Kyoto II: 2020rako emisioak murrizteko helburuak, 1990eko mailei dagokienez.}

\begin{tabular}{|l|c|}
\hline Herrialdea & Helburua \\
\hline Ukraina & $-\% 24$ \\
\hline Monako & $-\% 22$ \\
\hline EB-28, Islandia & $-\% 20$ \\
\hline Norvegia, Liechtenstein & $-\% 16$ \\
\hline Suitza & $-\% 15,8$ \\
\hline Bielorrusia & $-\% 12$ \\
\hline Kazakshtan & $-\% 5$ \\
\hline Australia (erreferentziazko urtea, 2000) & $-\% 0,5$ \\
\hline
\end{tabular}

Iturria: Kyotoko Protokoloaren B Eranskina, Dohako Zuzenketa eta gero (Nazio Batuak, 2013a).

Ikusten den bezala, Balin Kyotoko Protokoloa ordezkatuko zuen eta juridikoki loteslea zen mundu-akordioa hartu zenetik bost urtera ezarritako helburuak bete gabe jarraitzen zuen; hala ere, herrialde guztiek konpromiso bat ezarri zuten (Nazio Batuak, 2013b), 2015eko maiatzean klima-akordio loteslearen zirriborroa prest egotea —urte bereko abenduan Parisen onesteko-, nahiz eta jarraitzen zuen zehaztu gabe «protokoloak beste lege-tresna bat edo Konbentzioaren barruko legezko indarra duen akordioa» izan behar zuen. Nolanahi ere, Dohan agerian utzi zen «protokoloa sinatu eta bost urtera, herrialde industrializatuek jarraitzen dutela jarrera bateraezinak hartzen beren politika klimatikoetan» (Contreras, 2013: 68). Baina 2015ean ezinbestekoa izango litzatekeela hura ordezkatuko lukeen akordio loteslea onestea guztiek onartzeak ekarri zuen «Dohan klimaren negoziazioen etapa berria hastea» (Fernández eta Torres, 2013: 5).

Orain arte aztertutako Konferentzietan ikusi den bezala, gorabeherak izanik ere, baiezta daiteke EB zela klima-aldaketaren aurkako borrokaren buru eta lidergo hori eman zioten hiru argudio nagusiek bere jarrera indartu zezaketela nazioarteko eszenan berehalako etorkizunean: lehenengo eta behin, politika klimatikoa, garapen jasangarrirako funtsezko elementu gisa, Europako integrazio-prozesu orokorraren helburu bilakatu izana; bigarrenik, Europar Batasunak segurtasun energetikoa 
garapen jasangarriarekin lotzeko jarrera, agenda klimatikoaren garrantzia sendotu zuela kontuan hartuta; hirugarrenik, Europar Batasunak multilateralismoari klimaaldaketaren aurkako borrokan emaitza eraginkorrak lortzeko eskakizun gisa emandako garrantzia ${ }^{11}$.

Azken ideia hori indartzea izan zen aurretik, 2012ko ekainean, Rio de Janeiron egindako Garapen Jasangarriari buruzko Nazio Batuen Konferentzian («Río+20» izenez ezagutzen dena) garbi atera zen ia gauza bakarrenetakoa. 20 urte lehenago «Lurraren Goi Bileran» gertatutakoaz bestela, ia ez zen aurrerakuntzarik egon ingurumenaren babesari dagokionez, eta ez zen erabakirik hartu funtsezko bi gaien gainean: ekonomia berdea eta nazioarteko gobernamenduaren erakundeerreforma, ingurumenari dagokionez. Bigarren eremu horretan nabarmentzekoa da EBren proposamena, Afrikako herrialdeek eta Asiako hainbatek bultzatzen dutena, Ingurumenerako Nazio Batuen Programa nazioarteko erakunde bilakatzekoa; proposamen hori aurrez aurre ukatu zuten zenbait herrialdek, besteak beste, AEBk, Txinak edo Kanadak. Hala ere, esan bezala, Rioko bileran ateratako puntu positiboenetakoa izan zen «jarduketa aldeaniztunaren beharra eta egokitasuna berrindartzea, ingurumen-erronka globalei aurre egiteko unean» (Fernández eta Torres, 2013: 2).

Kopenhagen 2009an izandako frustrazioaren ondoren, Cancungo, Durbango eta Dohako Konferentzietan Kyotoko Protokoloa ordezkatuko duen testu juridiko lotesleari buruzko akordioa lortzeko emaitzarik eza kontuan hartuta, erabaki zen hurrengo bi konferentziak 2015ekoa prestatzeko izatea, orduan akordioari bide emateko.

Egia esan EBk berak onartu zuen Varsoviako Konferentzia 2013an eta Limakoa 2014an izango zirela Pariskoaren prestatze-faseak; bertan akordio globala lortzea espero zuen ${ }^{12}$. Zehazki, Varsovian Klima Aldaketari buruzko Nazio Batuen XIX. Konferentzian hartutako erabaki nagusia honako hau izan zen: Konbentzioaren Alderdiek Durbango Plataformari buruzko lanak areagotzeko hartutako akordioa, legezko indarra izango zuen eta 2015 eko abenduko bileran onets zitekeen protokolo berria prestatzearen inguruan. Funtsean, herrialdeek konpromisoa hartu zuten Parisen akordio batera heltzeko, guztiek Dohan eginiko zinari eutsiz.

Limako bilera dela-eta, EBk zuzenean planteatu zuen Konferentzia horrek balio izatea Klima Aldaketari buruzko Esparru Konbentzioaren Alderdiek 2015eko Parisko Konferentziara eramango zuten berotegi-efektuko gasen emisioak arintzeko konpromisoak aurkezteko. Horrela, denbora nahikoa egongo litzateke, proposamenak ikusita, dagozkion ekarpenak aztertzeko eta negoziazioak egokiro prestatzeko.

11. Gusev-ek (2011: 80-85) eginiko analisiari jarraitzen diogu. Gusevek ondorioztatzen du Kyotoko Protokoloa indarrean sartu zenetik, Europar Batasunak jakin duela aukerak aprobetxatzen eta bere eginbeharrei aurre egiten bere presentzia areagotzeko klima-aldaketaren aurkako borrokan eta, horrela, nazioarteko jardueran buru izan da eremu horretan, berezko eskubidez eta bere emisioak murrizteko legezko xedapen zehatzak hartu dituen eta horiek aplikatzeko beharrezkoak diren mekanismoak dituen munduko eskualde bakarra izateak ematen dion agintaritza moralarekin.

12. Horrela adierazi zuen Ingurumenaren Kontseiluak, EBk Varsoviako Konferentzian izango zuen jarrera ezarri zuenean. Europar Batasuneko Kontseilua, Varsovian, Klima Aldaketari buruzko Nazio Batuen Esparru Konbentzioan Aldeek eginiko 19. Konferentziaren Prestaketa, 14459/13 Dokumentua, 2013/10/08. 
Aldi horretan, EB bera kontzientzia hartzen hasi zen mundu mailan klima-ekintzan Europaren lidergoa galtzen ari zela. Aurretiko Nazio Batuen Konferentziek, batez ere Kopenhagekoaren porrotaren ondoren, agerian uzten zuten lidergo hori ahul zegoela. Ez zegoen zalantzarik, EBk ahalegin berezia egin zuela politika klimatiko koherentea eta handinahia hartzeko, eta horrek balio zezakeen erreferente gisa beste herrialde batzuentzat. Halaber, argi zegoen gorantz ari ziren eta garapenbidean zeuden herrialdeentzako laguntza-ekimen ugari sustatu zituela, klimaaldaketaren ondorioetara egokitzeko eta fenomeno horren aurkako borrokarako neurri eraginkorrak hartzeko. Hala ere, azken urteetan, agerian geratu zen zenbait alderdik eragotzi zutela EBk gai horren inguruan zeukan helburu nagusietako bat lortzea, eta, gainera, «beste eremu geografiko batzuetako gero eta gobernu gehiagok uste dute beren ekarpena ez dela nahikoa garrantzitsua eremu horretan munduko liderraren kategoria merezi izateko» (Contreras, 2013: 56).

Egoera horretan, EBk aukeratu zuen bere proposamenak aldatzea, aurreko Konferentzietan aurkeztutakoei dagokienez, eta klima-aldaketaren aurkako borrokan ekintza eraginkorrak indartutako apustua erakusteko ahalegina egitea. Horrela, EBk erabaki zuen Limako bileran, Parisko Konferentziarako berezko ekarpen gisa, 2030erako energia eta klima esparruaren (Europar Batzordea, 2014) barruan onetsitako helburuak aurkeztuko zituela ${ }^{13}$. Horrela, Europar Batasunak konpromisoa hartu zuen berotegi-efektuko gasen emisioak, 1990eko mailen aldean, gutxienez \% 40 murrizteko, 2030erako —\% 30 murriztu beharrean 2020rako, aurreko konferentzietan proposatu bezala-, eta 2050erako \% 80 eta \% 95 bitarteko murrizketa-mailara iristeko, horrela \% 50eko munduko murrizketa globalaren buru izateko.

Bestalde, AEBk eta Txinak gutxik espero zituzten proposamenak aurkeztu zituzten. Bi herrialdeek akordioa lortu zuten emisioen murrizketen inguruan eta Limako Konferentzia aurretik Obama eta Xi Jinping presidenteek akordioaren edukia jakinarazi eta «nazioarteko politika klimatikoaren sistema aldatu zuten» (Olabe, 2015: 66). Horren arabera, AEBk konpromisoa hartu zuen berotegi-efektuko gasen emisioak, 2005eko mailen aldean, \% 26-28 murrizteko 2015erako. Bere aldetik, Txinak konpromisoa hartu zuen emisioak zenbateko absolutuan murrizteko 2030etik aurrera.

Aurreikusi zitekeen bezala, 2014ko abenduan Liman egin zen Klima Aldaketari buruzko Nazio Batuen XX. Konferentziaren amaieran Varsovian hartutako antzeko erabakia hartu zen (Nazio Batuak, 2015), eta baieztatu zen Durbango Plataformari buruzko Lantaldeak bere lana osatu beharko lukeela, hurrengo konferentzian legezko indarra duen protokolo berria onetsi ahal izateko. Horretarako, «Ekintza Klimatikorako Limako Deia» izenez ezagutzen denak aurreikusten zuen 2015eko maiatzerako amaituta egotea horren inguruko negoziazio-testua. Hala ere, EBk, AEBk eta Txinak egindako proposamenak ikusita, Parisen egin beharreko hurrengo Konferentzian emaitza positiboak espero ziren.

13. Europar Batasuneko Kontseilua, Klima Aldaketari buruzko Nazio Batuen Esparru Konbentzioan Aldeen Konferentziak eginiko saioen 20. aldiaren eta Kyotoko Protokoloan Aldeen Bilerak eginiko saioen 10. aldiaren Prestaketa, 14196/14 Dokumentua, 2014/10/20. 


\section{Parisko Akordioa: arrakasta?}

EBk erabaki zuen ahalegin berezia egitea Parisko bileran akordio bat lortzeko, baina herrialde fidagaitzak erakartzea lortzeko ahaleginaren ondorioz, aurreko batzuetan erakutsitako ausardia ez zen bere proposamenetan islatu ${ }^{14}$. Europar Batasunak azpimarratzen zuen nolako garrantzia zuen bilerak; bertan, "alde guztiei (...) aplikagarria zaien eta nazio mailan zehaztutako arintzeko konpromiso handinahiak dituen akordio juridikoki loteslea eta handinahia (...)» hartu beharko litzateke, eta akordio horrek «epe luzera arintzeko helburua ezarri beharko luke, $2 \stackrel{\circ}{ }$ C-tik beherako gorakadaren helburuarekin bat etorriz» (urteko batez besteko tenperatura). Helburu hori lortzeko, Batasunak gogorarazten zituen Klima Aldaketari buruzko Gobernu-arteko Taldeak emandako datuak; horien arabera, berotegiefektuko gasen emisioek gutxienez \% 60 egin behar zuten behera 2050ean, 2010aren aldean, eta 0tik hurbil egon behar zuten, 2100erako. Horrek, aldi berean, herrialde garatuetako emisioak, 1990aren aldean, 2050erako \% 80 eta \% 95 bitartean murriztea beharko luke (IPCC, 2016).

EBren ekarpena izan zen Liman aurkeztutakoa, berotegi-efektuko gasen emisioak 2030erako, 1990aren aldean, \% 40 murrizteko helburu lotesleari dagokiona. AEBk eta Txinak ere Liman aurkeztutako ekarpen berdinak eraman zituzten Parisera. Ordea, AEBren negoziazioak eta jarrera ikusita, kontuan hartuta akordio berriaren sinadurari oztopoak jartzen jarraitzen zuela, EBk Kyotoko Protokoloa ordezkatzeko akordio loteslearen aldeko apustuari eutsi zion, baina uko egin zion zehapenak sar zitezen; izan ere, uste izan zuen horrek konbentzitu zitzakeela herrialde batzuk sinatzera. Hemen berriro ere ikusten dugu Europaren aldetik batean kale, bestean bale; izan ere, nahiz eta EBk emisioak \% 40 murrizteko berezko proposamen loteslea goratu behar den, beharbada pentsatuko dugu gehiegizkoa dela etengabe etsitzea eta zehapenik ez erreklamatzea beraiek aurkezten dituzten konpromisoak betetzen ez dituzten herrialdeentzat.

Klima Aldaketari buruzko Nazio Batuen XXI. Konferentzia Parisen egin zen, 2015eko azaroaren 30aren eta abenduaren 11ren artean. 195 herrialde partehartzaileek adostasunez hartu zuten «Parisko Akordio» (Nazio Batuak, 2016) ezaguna, juridikoki loteslea eta unibertsala den tresna. Edukien artean, honako hauek nabarmendu behar dira:

- Sinatzaile guztiek konpromisoa hartu dute berotegi-efektuko gasen emisioak murrizteko eta urteko batez besteko tenperaturaren igoera $2{ }^{\circ} \mathrm{C}$-tik behera mantentzeko, maila aurreindustrialei dagokienez, eta gorakada hori $1,5^{\circ} \mathrm{C}$ ra mugatzeko ahalegina egiteko.

- Sinatzaile guztiek aurkeztu behar dituzte beren emisioak arintzeko planak (Kyotoko Protokoloaz bestela, kontuan hartuta horretan herrialde garatuek baino ez zeukatela beren emisioak murrizteko betebeharra). Hala ere, herrialde bakoitzak tenperaturaren gorakadari eusteko helburu globala lortzeko egokitzat jotzen duen emisioen murrizketarako xedea ezartzen du.

14. Europar Batasuneko Kontseilua, Klima Aldaketari buruzko Nazio Batuen Esparru Konbentzioan Aldeen Konferentziak eginiko 21. saiorako eta Kyotoko Protokoloan Aldeen Bilerak eginiko 11. saiorako prestaketei buruzko Kontseiluaren Ondorioen Proiektua, 11926/15 Dokumentua, 2015/09/14. 
- Emisioak murrizteko plan horiek 2020tik aurrera aplikatuko dira —ordura arte Kyotoko Protokoloaren bigarren indarraldiak arautuko du-, helburuak 2025erako izanik. Bost urterik behin, emisioak arintzeko plan berriak aurkeztu eta aplikatu beharko dira.

- Akordioak klima-aldaketaren aurkako ondorioetara egokitzeko gaitasuna areagotzea jasotzen du, bai eta finantza-fluxuak klimarekin moldakorra den garapenera bideratuko duen ibilbidearekin bateragarria den maila batean kokatzea ere. Horren harira, 2020an egituratuta egon beharko du gutxienez 100.000 milioi dolarreko funtsak, batik bat herrialderik garatuenen eskutik, estatu ahulenei laguntzeko klima-aldaketaren aurrean. 2025etik aurrera, gorantz berrikusiko da.

Parisko Akordioa, oro har, akordio egokitzat jotzen da, eta arrakastatsutzat kalifikatzen da, baina, kasu horretan, pisu handiagoa du Kopenhageko porrotarekiko erkaketak. Bereziki positibotzat jotzen da orain arte kontu horretarako uzkur ziren herrialdeek, besteak beste, AEBk edo Errusiak eta, azkenaldian, Kanadak edo Japoniak, akordioa sinatzea. Nolabait, Parisko negoziazioen eta emaitzaren bidez, Durbanen hasitako joera bat sendotu zen, eta joera horrek «munduko arkitektura klimatikoaren ideia berriaren eraikuntza» islatzen du, eta bertan nabarmentzekoa da «lidergo triangeluarrerako igarobidea -Europar Batasuna, Ameriketako Estatu Batuak, BASIC—» eta bilatzen da «konpromisoak zatikatzea, batez ere arintzeko, eta, neurri txikiagoan, finantzamenduari dagokionez» (Bueno, 2016: 90 eta 92).

Beharbada gehiegi izango da esatea «2015eko Parisko Akordioa une garrantzitsua izan zela klima-aldaketaren aurkako munduko borrokan», baina egia da «munduko emisio ia guztiak betetzen dituen klima-aldaketaren inguruko alde anitzeko lehen akordioa dela» (Europar Batzordea, 2016: 2). Jakina, positiboa da herrialde parte-hartzaile guztiek adostu eta onartu izana lotesle gisa mende honen amaieran tenperaturaren gorakada $1,5 \stackrel{\circ}{\circ} \mathrm{C}$-ra mugatzeko konpromisoa, bai eta arintzeko neurriak hartzeko eta kontuak argi, garden eta bilakaeren segimendua egin ahal izateko moduan emateko konpromisoa ere. Izan ere, lehen aldiz aldaketa klimatikoaren nazioarteko erregimenean emisioen murrizketak ezartzen dira herrialde garatuentzat zein garapen-bidean daudenentzat (Demares, 2016: 68). Hala ere, marjina handia uzten zaie herrialdeei zehazteko nola eta noiz egingo dituzten emisioen murrizketak, eta egindako ahaleginen berri eman behar da, baina helburu kuantifikatu bereziak ezarri gabe, Kyotoko Protokoloak ezarritakoak bezalakoak ${ }^{15}$. Alderdi bikoitz horren bidez, baiezta daiteke «mundu hipokarbonikorako trantsizioak onespena jaso duela Parisen, baina abiadura eta sakontasuna oraindik zehazteko daudela» (Escribano eta Lázaro, 2016: 10).

Nabarmentzekoa da, beste behin ere, EBren jarrera, interes desberdinak dituzten eta, batzuetan, aurrez aurre dauden interesak dituzten herrialde taldeen arteko akordioari bide emateko. Hala ere, oraingoan kritika daiteke Europako proposamenetan antzematen den lagatzea; izan ere, emisioak murrizteko

15. Badago hau positiboki baloratzeko aukera, Kopenhageko porrotarekin alderatuz. Hain zuzen ere, horrelako porrota ekiditeko, emisioen murrizketan muga absolutorik ez jartzea erabaki zen (Lord Carnwarth, 2016: 5). Bestalde, Parisko Akordioak eduki arauemaile ahula duela onartuta ere, testuan betebehar gogorrak, betebehar ahulak eta ez-betebeharrak daudela defendatu daiteke (Rajamani, 2016). 
konpromisoak betetzen ez dituztenei zehapenak ezartzeari uko egiteko ideia onartu zen, akordio globalari bide emateko. Horrela, Parisko Akordioaren helburuak ezerezean gera daitezke, derrigorrezkoak izanik ere, horiek bete gabe utz daitezkeeta, horiek betetzen ez dituzten herrialdeentzat zehapenik jaso ez dela kontuan hartuta (Villaring, 2016: 27).

EBk Parisko Akordioaren gainean duen ikuspegi positiboaren oinarria zera da: ekonomia hipokarbonikora iristeko zenbait sektoretan, besteak beste teknologian, energian, ekonomian eta finantzetan, funtsezko aldaketa behar dela kontuan hartuta, akordio hori «aukera bat dela eraldaketa ekonomikorako, hazkunderako eta enplegurako». Izan ere, EBri bide ematen dio «energia berriztagarrien, efizientzia energetikoaren sustapenean aitzindaria izateak eta munduko eskalan karbonoemisio baxuak dituzten beste teknologia batzuen garapenean lehiatzeak dakartzan abantailak» aprobetxatzeko (Europako Batzordea, 2016: 5).

Parisko Akordioak indarrean sartzea aurreikusten du, berotegi-efektuko gasen emisio globalen \% 55 baino gehiago batzen duten 55 herrialdek baino gehiagok berretsi ondoren. EBk oro har 2016ko urrian berretsi izanak ekarri zuen urte bereko azaroaren 4an indarrean sartzea. Paradoxikoki, AEBk eta Txinak akordioa aurretik ere berretsi zuten -irailean-, baina EBko 28 estatu kideetako zazpik baino ez zuten berretsi Batasunaren taldearekin. Oraindik 12 estatu kide geratzen ziren berresteko (horien artean Espainia), Klima Aldaketari buruzko Nazio Batuen XXII. Konferentziaren hasieran; konferentzia Marrakexen egin zen, 2016ko azaroaren 7aren eta 18aren artean.

Parisko Akordioaren berrespenaren berri ematen zuen bitartean, EBk publiko egiten zituen Marrakexeko Konferentziara eramango zituen proposamenak ${ }^{16}$. Batasunak jakinarazi zuen Kyoto II-k zehazten zuen 2020rako helburua beteko zuela; izan ere, 2014ko emisio-mailek \% 23ko murrizketa baieztatzen zuten, 1990aren aldean, eta politika klimatikoak aplikatzen jarraitzeko konpromisoa errepikatzen zen.

4. taula. Berotegi-efektuko gasen emisioen murrizketa EBn, 1990ari dagokionez (erreferentziazko urtea $=100$ ), Kyoto eta Kyoto II.

\begin{tabular}{|c|c|c|c|c|c|c|c|c|}
\hline & $\mathbf{1 9 9 5}$ & $\mathbf{2 0 0 0}$ & $\mathbf{2 0 0 5}$ & $\mathbf{2 0 1 0}$ & $\begin{array}{c}\text { Kyoto: } \\
\text { helburua 2012 }\end{array}$ & $\mathbf{2 0 1 2}$ & $\begin{array}{c}\text { Kyoto II: } \\
\text { helburua 2020 }\end{array}$ & $\mathbf{2 0 1 4}$ \\
\hline EB & 94,1 & 92,1 & 93,2 & 85,7 & $92(-\% 8)$ & 81,8 & $80(-\% 20)$ & 77 \\
\hline
\end{tabular}

Iturria: Egileak moldatua Eurostat-eko datuak erabiliz.

Marrakexeko bilerako parte-hartzaileen helburua zen Parisko Akordioaren edukiak zehaztea eta, horretarako, ibilbide-orri bat zehaztea, horiek abian jartzeko. Bileran, alderantzizko datu batzuk eman ziren ezagutzera, eta, horien artean, batzuek emaitza positiboetarako bide ematen zuten, eta, beste batzuek emaitza

16. Europar Batasuneko Kontseilua, Marrakexen egingo diren Klima Aldaketari buruzko Nazio Batuen Esparru Konbentzioko bileren prestaketak - Kontseiluaren Ondorioak, 12807/16 Dokumentua, 2016/09/30. 
pesimistagoak ematen zituzten ${ }^{17}$. Alde positiboan nabarmendu behar da ordurako 105 herrialdek berretsi zutela Parisko Akordioa, munduko emisioen \% 80ren arduradun zirenek. Ezagutu ziren emisioen murrizketa-datuen artean, bi herrialde nabarmendu ziren: alde batetik, Txinak, berotegi-efektuko emisio guztien \% 29ren arduradunak, azken hamarkadan urteko batez besteko gorakada \% 5,3koa izanik, lortu zuen 2015ean emisioen \% 0,7 murriztea, eta, bestetik, AEBk, bigarren herrialde kutsatzaileenak, emisioen \% 15ekin, \% 2,6 murriztu zituen.

Ordea, Munduko Meteorologia Erakundeak Marrakexeko Konferentzian tenperaturen azken txostenaren aurrerapena aurkeztu zuen; bertan aurreikusten zuen 2016aren amaieran batez besteko tenperatura globala balio aurreindustrialak baino 1,2 ${ }^{\circ} \mathrm{C}$ altuago izango zela, 1961-1990 aldiko batezbestekotik ia gradu bat gainetik, kontuan hartuta hori hartzen dela erreferentziatzat ${ }^{18}$. Bestalde, AEBren eta Txinaren datuak positiboak ziren, bai eta, zalantzarik gabe, EBk 1990aren eta 2014aren artean eginiko emisioen murrizketaren bilakaera ere, kontuan hartuta urtean \% 1 murriztu zela aldi horretan; ordea, 2015eko datuek erabat amaitu zuten joera on horrekin; izan ere, Europako emisioek \% 1,4 egin zuten gora, kausa nagusia ikatzaren erabilera handiagoa izan zela.

Hala ere, Marrakexeko Konferentzian albiste entzutetsuena Donald Trumpen garaipena izan zen AEBren presidentetza-hauteskundeetan; Donald Trumpen asmoa da Ipar Amerikako herrialdeak Parisko Akordioa bazter uztea. Neurri batean, horren ondorioz, herrialde guztien ordezkariek akordio hori bultzatzeko adierazpena onartu zuten ${ }^{19}$. Nahiz eta ondorio praktikorik ez duen, adierazpen politikoa da, eta bertan baieztatzen da Parisko Akordioaren ondoriozko berotzearen aurkako borroka atzeraezina dela; klima-aldaketaren aurkako borrokan konpromiso gehiagoz jardutea defendatzen da, eta garapen-bidean dauden herrialdeei proiektu klimatikoak finantzatzeko laguntza areagotzera behartzen da. Arrazoi beragatik, 2015ean adostutakoa garatzeko jarraitu beharreko egutegia ezartzea lortu zen. Petrolio-interes handiak dituzten herrialdeen susmoak gorabehera, EBk eta garapen-bidean dauden herrialde gehienek eginiko presioaren bidez, egutegi bat itxi behar izan zen, eta, horren bidez, herrialde guztiek hartu zuten konpromisoa 2018rako Parisko Akordioaren araudi-garapena amaitzeko. Horrela, nazioarteko komunitateak akordioa defendatzeko borondatea berretsi zuen eta, aldi berean, aldaketa klimatikoaren aurkako borroka atzeraezina dela agertu (Olabe, 2017: 116).

17. Datuen iturria: Marrakech COP22/CMP12/CMA1, Conference des Nations Unies sur les Changements Climatiques, cop22.ma (2016ko azaroaren 11n kontsultatuak).

18. Horri gehitu behar zaio dirudienez ez dela behar bezala hasi Parisko Akordioan aurreikusitako helburua betetzeko lana; izan ere, herrialdeek berotegi-efektuko gasak murrizteko aurkeztu zituzten konpromisoek $3{ }^{\circ} \mathrm{C}$-ko tenperatura-igoera dakarte (Marcellesi, 2015). Zehazki, emisioen \% 94ren arduradun diren 185 herrialdek iragarritako konpromisoen inguruko lehen estimazioek tenperaturen gorakada zekarten mende amaierarako, 2,7 ${ }^{\circ} \mathrm{C}$ eta $3,4{ }^{\circ} \mathrm{C}$ artekoa (Climate Action Tracker, 2015).

19. Marrakech action proclamation for our climate and sustainable development, Klima Aldaketari buruzko Nazio Batuen Esparru Konbentzioaren web orrialdean argitaratua (http://unfccc.int/files/meetings/ marrakech_nov_2016/application/pdf/marrakech_action_proclamation.pdf), 2016ko azaroaren 18an. 


\section{Ondorioak}

2007ko Baliko Konferentzian Kyotoko Protokoloa ordezkatuko duen akordio loteslea lortzeko prozesua hasi zen. Poznanen, 2008an, bidea prestatu ondoren, akordioa Kopenhagen lortu behar zen, 2009an. Ez zen horrela izan. Herrialde guztiek 2050erako berotze globalaren igoera mugatu behar zela onartu bazuten ere, ez zen hartu konpromisorik berotegi-efektuko gasak murrizteko Kyotoko Protokoloaren iraunaldia bukatu eta gero. Porrotaren ondoren negoziazioak asko moteldu ziren, 2010ean, Cancuneko Konferentzian argi gelditu zenez, herrialde taldeen eskari eta interesak ezberdinak zirelako eta guztiei erantzuna eman behar zitzaielako akordio globala lortzeko. Durbaneko Konferentzian, 2011n, eztabaidekin jarraitzea erabaki zen, besterik ez, 2012an akordioa errazteko. Horrela, Dohako Konferentzian, Kyoto II onartu zen. Ordea, hasierako Kyotoko Protokoloa sinatu zuten herrialde industrializatu guztiek ez zuten Kyoto II-k ekartzen zuen konpromisoa hartu.

Prozesuak izan zuen hasierako porrota eta, ondoren, negoziazioen erritmo motela eta emaitzarik eza kontuan hartuta, akordio loteslea lortzeko helmuga gisa ezarri zen 2015ean Parisen egin beharreko Konferentzia. Hori dela-eta, 2013ko Varsoviako Konferentziak eta 2014ko Limako Konferentziak akordioa lortzea erraztu behar zuen testuingurua prestatu zuten. Azkenik, Parisen juridikoki loteslea den tresna unibertsala onartu zen. Parisko Akordioaren arabera, herrialde guztiek konpromisoa hartu zuten berotegi-efektuko gasen emisioak murrizteko eta urteko batez besteko tenperatura globalaren igoera $2{ }^{\circ} \mathrm{C}$-tik behera mantentzeko. Hala ere, murrizketarako helburu kuantifikaturik ez zen zehaztu. Konpromiso hori herrialde guztiek berretsi zuten iazko Marrakexeko Konferentzian.

Testuan ikusi denez, EBk zeregin protagonista izan du aipatu den prozesuaren bilakaeran. Europak ekonomia garatuenen inplikazioa lortu nahi izan du klimaaldaketaren aurkako borrokan eta garapen-bidean dauden herrialdeentzako laguntzan, borrokan duten parte-hartzea eraginkorra izateko. Ukaezina da horrek bide eman diola EBri garatzeko bidean dauden ekonomien eta garapen-bidean dauden herrialdeen solaskide pribilegiatua izateko nazioarteko klima-negoziazioetan.

Hala ere, AEBk munduko klima-akordio berria bilatzeko negoziazioetan protagonismoaren lehen lerroan egoteko egin duen ahaleginak, kontuan hartuta helburu hori zati batean bete egin zela Kopenhageko Konferentzian, Txinarekin dituen interesekin bat egiteagatik, nolabaiteko garrantzia kendu zion EBren etengabeko ahaleginari. Izan ere, AEB eta Txina oztopo bilakatu dira klimari buruzko nazioarteko negoziazioetan, batek konpromisoa hartzen ez bazuen besteak ere ez zuelako hartzen. Harrezkero, EBk jarraitu du izaten klima-aldaketaren aurkako borrokan proposamen ausartenak mahai gainean jarri dituen ekonomia, nahiz eta munduko klima-ekintzan lidergoa zalantzan jarri duten argi-ilunak antzeman diren. Estatu kideen egoeren desberdintasunak, 2008ko krisiaren ondorio ekonomikoen aurrean, eta euroguneak 2010etik aurrera izan duen atzeraldiak ez diote erraztasunik eman EBri oro har lidergo horren nagusitasuna berreskuratzeko ahaleginean.

Zenbait herrialdek, besteak beste AEBk edo Txinak, klima-aldaketari buruzko Nazio Batuen konferentzietan hartutako erabakietan eragina izatea lortu dutela ikusi 
da, nahiz eta jarrera pasiboa izan edo proposamen aurreratuenei uko egin, horien tartean europarrak zeudela kontuan hartuta. Europako oinarrietatik hurbil dauden herrialde batzuk ere, esaterako Japonia eta Kanada, Europatik aldentzen ari ziren, kutsatzaileenen jarreraren aurrean. Horren ondorioz, EBk murriztu egin du exijentziamaila bere proposamenetan jasotako erreklamazioetan, ekonomia aurreratu eta kutsatzaile horiek erakartzeko, eta, aldi berean, garapen-bidean dauden herrialdeen proposamenen hurbiltasunari eutsi dio.

Horrela, EBk azken urteotan nazioarteko foroetan aurkezteko hartu dituen proposamen eta helburuek erakutsi dute Batasunak bikoiztu egiten zituela ahaleginak, behin betiko nazioarteko akordio loteslea lortzeko, berotze globala gelditzeko asmoz. Hala erakutsi zuten Parisko Akordioa ekarri zuten negoziazioek, baina nabarmena izan zen jadanik lidergoa partekatzen dela Txinarekin eta AEBrekin, bi herrialde horien arteko akordioa dela medio.

\section{Bibliografia}

Bueno Rubial, M.P. (2016): «El Acuerdo de París: ¿una nueva idea sobre la arquitectura climática internacional?», Relaciones Internacionales, 33.

Camarero Rodríguez, F. (2008): «Bali y el largo camino del Protocolo de Kioto», Seguridad y Medio Ambiente, 109.

Climate Action Tracker (2015): $2.7^{\circ} \mathrm{C}$ is not enough - we can get lower, 2015eko abenduaren 8a, <climateactiontracker.org >.

Europar Batzordea (2010a): La política climática internacional posterior a Copenhague: una intervención inmediata para reactivar la lucha global contra el cambio climático, 2010eko martxoaren 9ko komunikazioa, COM (2010), 86 amaiera.

(2010b): Emissions trading: EU ETS emissions fall more than $11 \%$ in 2009 (IP/10/576), Brusela, 2010eko maiatzaren 18a.

(2014): Un marco estratégico en materia de clima y energía para el período 20202030, 2014ko urtarrilaren 22ko komunikazioa, COM(2014), 15 amaiera.

(2016): El camino desde París: evaluar las consecuencias del Acuerdo de París y complementar la propuesta de Decisión del Consejo relativa a la firma, en nombre de la Unión Europea, del Acuerdo de París adoptado en el marco de la Convención Marco de las Naciones Unidas sobre Cambio Climático, 2016ko martxoaren 2ko komunikazioa, COM (2016), 110 amaiera.

Contreras, D. (2013): «El papel de la Unión Europea en las negociaciones internacionales sobre cambio climático», Observatorio Medioambiental, 16. liburukia.

Demares, M. (2016): «La importancia de la gobernanza climática global y de la vigésimo primera Conferencia de las Partes en la lucha contra el Cambio Climático», Observatorio Medioambiental, 19. liburukia.

Escribano Francés, G. eta Lazaro Touza, L. (2016): «Energía y clima en 2016: en busca de una gobernanza policéntrica», ARI (Real Instituto Elcano), 28.

Fernández Egea, R.M. eta Torres Camprubí, A. (2013): «Crónica de Derecho Internacional del Medio Ambiente (enero - diciembre 2012)», Revista Electrónica de Estudios Internacionales, 25.

García Lupiola, A. (2010): «Kopenhagueko Klima Aldaketari buruzko Konferentzia: helburua Mexikon lortu behar», Uztaro, 73. 
Gusev, A.S. (2011): “Climate Change Issues in a Transatlantic Context», L'Europe en formation, 360.

IPCC - Klima Aldaketari buruzko Gobernu-arteko Taldea (2016) Cambio climático 2014: Informe de síntesis. Contribución de los Grupos de trabajo I, II y III al Quinto Informe de Evaluación del Grupo Intergubernamental de Expertos sobre el Cambio Climático [Idazketa talde nagusia, R.K. Pachauri eta L.A. Meyers (editoreak)], IPCC, Geneva.

Isbell, P. eta Steinberg, F. (2010): «Key Strategic Decisions for Europe in Energy and Climate Change», ARI (Real Instituto Elcano), 76.

Lázaro Touza, L. (2010): “Cambio climático: frenazo en Copenhague; próxima estación: México 2010 (COP 16)», ARI (Real Instituto Elcano), 9.

Lázaro Touza, L. (2011): «El papel de la Unión Europea en la gobernanza global en materia climática», Cuadernos Europeos de Deusto, 45.

Lázaro Touza, L. (2012): «Durban (COP17): resucitando el Protocolo de Kioto y retrasando la acción global hasta 2020», ARI (Real Instituto Elcano), 19.

Lord Carnwarth, J.S.C. (2016): “Climate Change Adjudication after Paris: A Reflection», Journal of environmental law, 28. liburukia, 1.

Marcellesi, F. (2015): «El Acuerdo de París sobre clima: entre milagro, desastre y (posible) punto de inflexión», <www.efeverde.com>, 2015eko abenduaren 16a.

Márcio Cruz, P. eta Bodnar, Z. (2011): «El clima como necesidad de gobernanza transnacional: reflexiones post-Copenhagen 2009», Revista Aranzadi de Derecho Ambiental, 19.

Mora Ruiz, M. (2013): «La ordenación jurídico-administrativa de las energías renovables como pieza clave en la lucha contra el cambio climático: ¿Un sector en crisis?», Actualidad Jurídica Ambiental, 32.

Nazio Batuak (1998): Protocolo de Kioto de la Convención Marco de las Naciones Unidas sobre Cambio Climático, FCCC/INFORMAL/83, New York.

, (2008): «Decisión 1/CP.13 - Plan de Acción de Bali», Informe de la Conferencia de las Partes sobre su $13^{\circ}$ período de sesiones, celebrado en Bali del 3 al 15 de diciembre de 2007 - Segunda parte: Medidas adoptadas por la Conferencia de las Partes en su $13^{\circ}$ período de sesiones (FCCC/CP/2007/6/Add.1), 2008ko martxoaren 14a.

, (2010a): «Decisión 2/CP.15 - Acuerdo de Copenhague», Informe de la Conferencia de las Partes sobre su 15ำ período de sesiones, celebrado en Copenhague del 7 al 19 de diciembre de 2009 - Segunda parte: Medidas adoptadas por la Conferencia de las Partes en su 15ํㅜ período de sesiones (FCCC/CP/2009/11/Add.1), 2010eko martxoaren 30a.

(2010b): Cambio climático: continúan las negociaciones, Servicio de Noticias, 2010eko otsailaren 2a, <www.un.org >.

(2010c): Third of Countries Show Promising Gains in Low Carbon Economic Growth Since the Copenhagen Climate Accord, Nazio Batuen Ingurumenarako Programa, 2010eko apirilaren 23a, <www.unep.org>.

(2011): «Decisión 1/CP.16 - Acuerdos de Cancún», Informe de la Conferencia de las Partes sobre su $16^{\circ}$ período de sesiones, celebrado en Cancún del 29 de noviembre al 10 de diciembre de 2010 - Segunda parte: Medidas adoptadas por la Conferencia de las Partes en su $16^{\circ}$ período de sesiones (FCCC/CP/2010/7/ Add.1), 2011ko martxoaren 15a.

(2012): «Decisión 1/CP.17 - Plataforma de Durban para una acción reforzada», Informe de la Conferencia de las Partes sobre su $17^{\circ}$ período de sesiones, celebrado en Durban del 28 de noviembre al 11 de diciembre de 2011 - Segunda parte: Medidas adoptadas por la Conferencia de las Partes en su 17ํㅜ período de sesiones (FCCC/CP/2011/9/Add.1), 2012ko martxoaren 15a. 
, (2013a): «Decisión 1/CMP.18 - Enmienda al Protocolo de Kioto de conformidad con su artículo3, párrafo 9 (Enmienda de Doha)», Informe de la Conferencia de las en calidad de reunión de las Partes en el Protocolo de Kioto sobre su octavo período de sesiones, celebrado en Doha del 26 de noviembre al 8 de diciembre de 2012 - Segunda parte: Medidas adoptadas por la Conferencia de las en calidad de reunión de las Partes en el Protocolo de Kioto sobre su octavo período de sesiones (FCCC/KP/CMP/2012/13/Add.1), 2013ko otsailaren 28a.

(2013b): «Decisión 2/CP.18 - Promoción de la Plataforma de Durban», Informe de la Conferencia de las Partes sobre su $18^{\circ}$ período de sesiones, celebrado en Doha del 26 de noviembre al 8 de diciembre de 2012 - Segunda parte: Medidas adoptadas por la Conferencia de las Partes en su $18^{\circ}$ período de sesiones (FCCC/ CP/2012/8/Add.1), 2013ko martxoaren 15a.

, (2015): «Decisión 1/CP.20 - Llamado de Lima para la Acción Climática», Informe de la Conferencia de las Partes sobre su $20^{\circ}$ período de sesiones, celebrado en Lima del 1 al 14 de diciembre de 2014 - Segunda parte: Medidas adoptadas por la Conferencia de las Partes en su $20^{\circ}$ período de sesiones (FCCC/CP/2014/10/ Add.1), 2015ko otsailaren 2a.

(2016): «Decisión 1/CP.21 - Aprobación del Acuerdo de París», Informe de la Conferencia de las Partes sobre su 21er período de sesiones, celebrado en París del 30 de noviembre al 13 de diciembre de 2015 - Segunda parte: Medidas adoptadas por la Conferencia de las Partes en su 21er período de sesiones (FCCC/CP/2015/10/Add.1), 2016ko urtarrilaren 29a.

Olabe Egaña, A. (2015): «El camino hacia París», Política Exterior, 29. liburukia, 163.

Olabe Egaña, A. (2017): “Cambio climático en tiempos de incertidumbre», Política Exterior, 31. liburukia, 175.

Rajamani, L. (2016): «The 2015 Paris Agreement: Interplay Between Hard, Soft and NonObligations", Journal of environmental law, 28. liburukia, 2.

Villaring Tomás, J.M. (2016): «La COP21 acerca el futuro renovable», Cuadernos de Energía, 47. 
